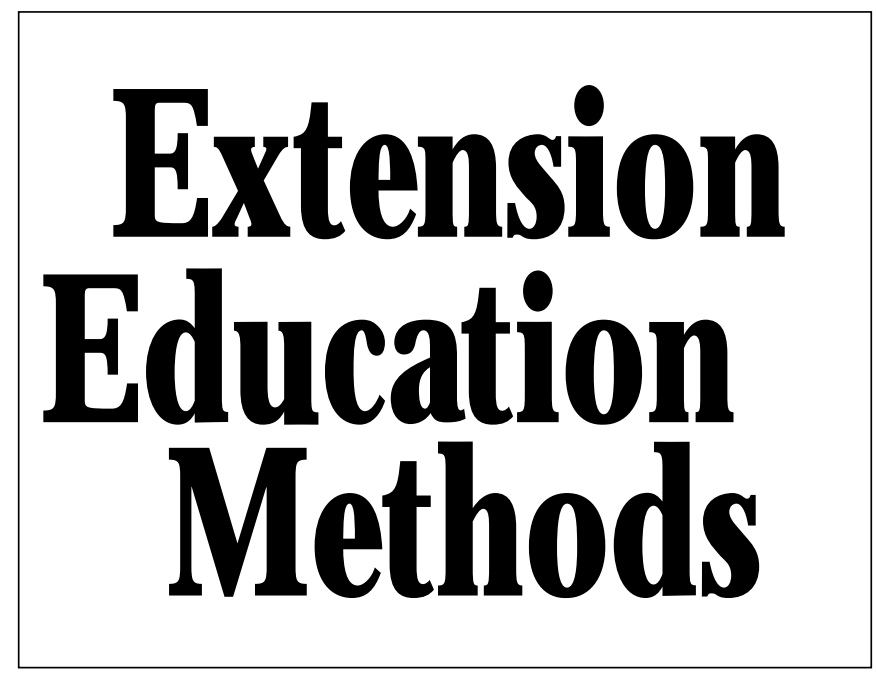

Adoption of Landscape Management Practices by Florida Residents

\author{
G lenn D. I srael, ${ }^{1}$ J anice O . Easton, ${ }^{2}$ and \\ Gary W. Knox ${ }^{3}$
}

ADDITIONAL INDEX WORDS. extension, evaluation, program delivery

\begin{abstract}
Summary. The Florida C ooperative E xtension Service (FCES) teaches residents the importance of proper landscaping practices. FCE S offers several educational programs that teach residents how to integrate energy and water conservation, pest management, and waste recycling practices into their home landscapes. In 1997, extension staff and volunteers planned and conducted environmental landscape management (ELM) programs resulting in $>\mathbf{8 0 0 , 0 0 0}$ customer contacts. A survey was conducted to measure the adoption of recommended best management practices by program participants and nonparticipants. Results show that, of 39 practices examined, M aster $\mathbf{G}$ ardener trainees increased the number of practices used by an average of 7.3, while educational seminar and publications-only participants increased by an average of $\mathbf{4 . 5}$ and $\mathbf{2 . 8}$ practices, respectively. N onparticipants showed essentially no change. When practices are examined one at a time, the $M$ aster $\mathbf{G}$ ardeners made statistically significant increases in $\mathbf{2 8}$ of the 39 recommended practices. E ducational seminar and publications-only participants made similar gains in $\mathbf{3 1}$ and 6 practices, respectively, and the nonparticipant comparison group made significant increases in $\mathbf{2}$ practices and decreases
\end{abstract}

\footnotetext{
U niversity of Florida, P.O. Box 110285, Gainesville, FL 32611-0285.

Presented at the annual meeting of the American Evaluation Association, San D iego, CA, N ovember, 1997. U niversity of Florida Florida Agricultural Experiment Stationjournal paper R-06157.T he cost of publishing this paper was defrayed in part by the payment of page charges. U nder postal regulations, this paper therefore must be hereby marked advertisement solely to indicate this fact.

1Professor, Program D evelopment and Evaluation Center; email: gdi@gnv.ifas.ufl.edu. ${ }^{2}$ Former research assistant, Program D evelopment and Evaluation Center. ${ }^{3} \mathrm{Associate}$ professor, $\mathrm{N}$ orth Florida REC.
}

in 8. The results suggest that the publications-only strategy for delivering information to homeowners is less effective than strategies combining educational seminars or intensive training with relevant publications.

$\mathrm{T}$ hough concern for the environment continues to resonate with the public, homeowners are often slow to recognize the impact of their landscape design and maintenancepracticeson surrounding ecosystems. Environmental degradation can occur to our water, land, and biotic resources from the cumulative impacts of individual homeowners' fertilization, irrigation, pest management, and other landscaping practices (Beverly et al., 1997). For example, using recommended irrigation practices can save $\approx 30 \%$ of outdoor water use, while redesigning the home landscape and irrigation system and using proper irrigation practices can save $75 \%$ to $80 \%$ (Gilman and Park Brown, 1991; Karlik, 1992; N elson, 1987). Florida Cooperative Extension Service (FCES) is teaching residents the importance of proper landscaping practices to address these environmental concerns. It offers several educational programs that promote the adoption of environmentally sound practices in the design and management of residential landscapes. These programs teach homeownershow to integrateenergy and water conservation, pest management, waste recycling, and other practices into their landscapes. Although delivery methods vary among counties, program content and environmental landscaping principles are consistent.

In 1997, FCES staff and volunteers planned and conducted environmental landscape management (ELM) programs resulting in $>800,000$ customer contacts. Consumers learned about EL M through $>500$ programsin 46 of Florida's 67 counties. Personnel and operating expenses for the ELM programs in fiscal year 1997 was $\approx 2$ million dollars. Given FCES's investment of resources in the ELM program, a team of county and state Extension faculty wanted to assess program impact and compare the effectiveness of delivery methods. I nformation about the impact of different delivery methods is critical to improving the program's efficiency. If one delivery method is ineffective, then efforts can be modified or redirected to other strategies. I mpact information is also used to meet increasing accountability requirements of state and federal legislative bodies, county officials, and the public at large. This paper addresses these issues by comparing the adoption of recommended landscaping practices by participants in three versions of theE LM program with anonparticipant comparison group.

\section{Environmental landscape management programs}

County extension faculty often customizethe delivery of ELM programsto fit theeducational interestsand needs of the local audience. These programs fit into three categories: $M$ aster Gardener (M G) training, educational seminars, and publications only. Florida's M G program provides residents with an intensive education of horticultural practices. The program requires that participants attend $50 \mathrm{~h}$ of training on topics relating to landscape management. After satisfactorily completing the training and meeting program requirements, M Gs are expected to volunteer $50 \mathrm{~h}$ of in-kind services within 1 year of their training. Trainees also receive the M G handbook and other relevant resource materials.

Educational seminars and workshops lasting from 1 to 6 
Table 1. Distribution of environmental landscape management survey respondents' property attributes by type of program.

\begin{tabular}{|c|c|c|c|c|c|c|c|c|}
\hline & \multicolumn{8}{|c|}{ Program type } \\
\hline & \multicolumn{2}{|c|}{$\begin{array}{l}\text { Master } \\
\text { G ardener } \\
(\mathbf{n}=\mathbf{1 3 4})\end{array}$} & \multicolumn{2}{|c|}{$\begin{array}{c}\text { Seminar } \\
(n=320)\end{array}$} & \multicolumn{2}{|c|}{$\begin{array}{c}\text { Publications } \\
\text { only } \\
(n=72)\end{array}$} & \multicolumn{2}{|c|}{$\begin{array}{c}\text { Nonparticipant } \\
\text { group } \\
(\mathbf{n}=186)\end{array}$} \\
\hline & $n$ & $\%$ & $\mathrm{n}$ & $\%$ & $\frac{1}{n}$ & $\%$ & $\mathbf{n}$ & $\%$ \\
\hline \multicolumn{9}{|l|}{ Property type } \\
\hline Home & 102 & 77 & 287 & 90 & 65 & 90 & 152 & 83 \\
\hline Mobile home & 7 & 5 & 16 & 5 & 3 & 4 & 17 & 9 \\
\hline O ther (e.g., condos) & 24 & 18 & 17 & 5 & 4 & 6 & 14 & 8 \\
\hline \multicolumn{9}{|l|}{$M$ aintained by } \\
\hline Respondent & 122 & 92 & 272 & 85 & 61 & 85 & 121 & 66 \\
\hline Lawn service & 6 & 4 & 28 & 9 & 6 & 8 & 41 & 22 \\
\hline O ther & 5 & 4 & 19 & 6 & 5 & 7 & 21 & 12 \\
\hline \multicolumn{9}{|l|}{ Area } \\
\hline 1/ 8 acre ( $0.05 \mathrm{ha})$ & 20 & 15 & 80 & 26 & 21 & 30 & 63 & 35 \\
\hline 1/ 4 acre (0.10 ha) & 25 & 19 & 94 & 30 & 24 & 34 & 53 & 29 \\
\hline $1 / 3$ to $1 / 2$ acre ( 0.13 to $0.20 \mathrm{ha})$ & 33 & 25 & 75 & 24 & 15 & 21 & 33 & 18 \\
\hline 1 acre (0.40 ha) & 18 & 14 & 31 & 10 & 4 & 6 & 17 & 9 \\
\hline$>1$ acre (0.40 ha) & 36 & 27 & 29 & 9 & 7 & 9 & 14 & 8 \\
\hline \multicolumn{9}{|l|}{ I rrigation system } \\
\hline Permanent & 42 & 31 & 144 & 45 & 41 & 57 & 75 & 40 \\
\hline $\mathrm{N}$ onpermanent & 92 & 69 & 176 & 55 & 31 & 43 & 110 & 60 \\
\hline
\end{tabular}

$\mathrm{h}$ are offered to residents on topics relating to environmental landscape management. Workshops such as the "Eco-Gardening Conference," "L awn and Landscape I mprovement," and "Florida Yards \& N eighborhoods" offer information on composting, backyard habitats, landscape design, and conservation. In some counties, trained volunteers provide direct assistance to individual homeowners. Participants al so receive a copy of relevant publications, including the Florida Yards and N eighborhoods (FYN) handbook.

Some residents only obtain copies of environmental landscape management publications (e.g., the FYN handbook) and do not attend educational seminarsor theintensive $M G$ training.

\section{Methods}

Surveys collected information on landscape design and maintenance practices, as well as homeowner attributes, sources of landscaping information, and attitudes concerning landscape management. $D$ ata was first collected from a nonparticipant comparison group in 1993 to establish a baseline. Data was collected from program participants immediately before and $\approx 6$ months after the educational programs during the FY97 program year. A nonequivalent control group design wasused for the evaluation (Campbell and Stanley, 1963). Although this design assesses program impacts, it is subject to coverage and nonresponse bias. Coverage refers to the extent to which participation by the target population achieves the levels specified in the program design (Rossi and F reeman, 1993). N onresponse bias occurs when nonrespondents differ from respondents, which is usually problematic when response rates are low.

Survey data was collected from 134 Clay, Baker, D uval, Leon, M onroe, N assau, Putnam, St. Johns, and St. Lucie county residents who were enrolled in 1996-97 M G programs. M Gs yielded a higher response rate (63\%) than any other group. In 1996 and 1997, Brevard, Broward, $\mathrm{H}$ illsborough, $\mathrm{M}$ anatee, $\mathrm{M}$ onroe, and St. Lucie counties collected preprogram and followup data on 320 participants who atten ded educational seminars (a response rate of $45 \%$ ). $D$ ata was collected from 72 residents of $M$ anatee and $\mathrm{H}$ illsborough counties who received publications only (a response rate of $54 \%$ ). A nonequivalent comparison group was selected from 23 counties having proactive environmental landscape extension programs. A sample of licensed drivers (18 years of age or older) yielded a response rate of $57 \%$ or 186 usable instruments during the 1993 baseline survey.

Since the development of the ELM program, the survey instrument has been revised several times. Q uestions that have remained the same for each survey version are included in this paper. Specifically, the analysis focused on the use of 39 best management practices- practices FCES recommends to homeowners that relate to landscape design, irrigation, fertilization, pest management, mowing and pruning, and mulching. An analysis of variance was calculated to determine whether program type impacted net adoption across the set of practices. M cN emar's test was used to assess whether the change in adoption of specific practices between the pre- and followup surveys was significant (Sokal and Rohlf, 1995).

\section{Attributes of respondents}

M ore than $75 \%$ of the respondents from each group indicated that they lived in single-family homes. A somewhat higher percentage of M G trainees reported living in condos, apartments and other types of housing than did other groups' members (Table 1). M ore M Gs also maintained their own landscapes and were likely to own more acreage than members of any other group. N onparticipants from the comparison group were less likely to maintain the landscape. Less than half of those in the M G, seminar, and nonparticipant groups indicated that they owned a permanent irrigation system, while $57 \%$ of the publications-only group al ready had a system. 


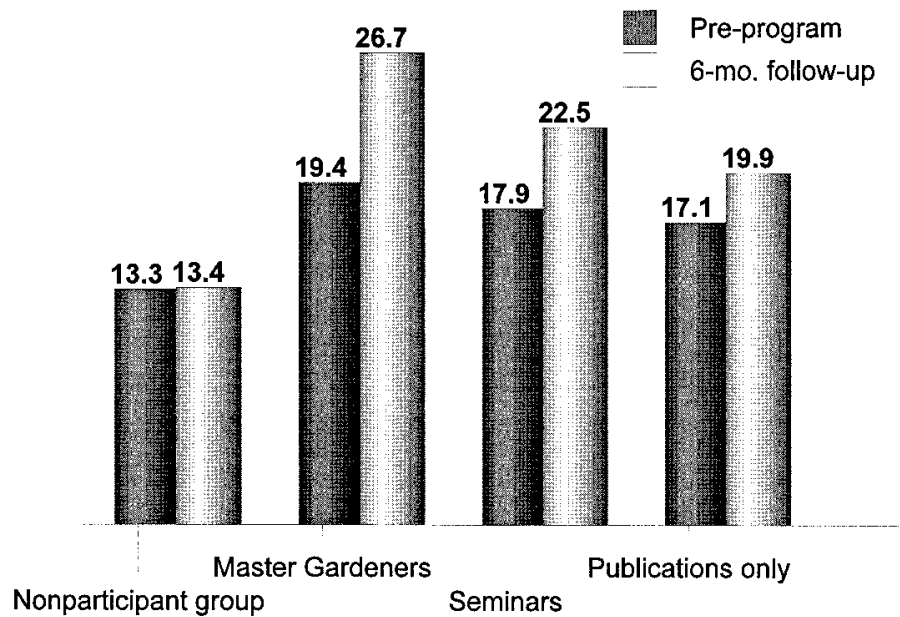

Fig. 1. Mean number of environmental landscape management practices used by program type.

\section{Assessing program impacts}

Preprogram surveys indicated that respondents in the groups were using an average of between 13 and 19 of 39 practices before the programs (Fig. 1). Six months after the programs, the average number of practices used by participants showed an increase, while that for nonparticipants remained unchanged. M Gs had the largest net increase in practice adoption, followed by seminar and publicationsonly participants, respectively.

Thetype of program significantlyinfluenced the change in the number of practices used by respondents $(F=31.7$; $p=0.001$ ). H owever, thetype of property, person maintaining the property, presence of a permanent irrigation system, and parcel size did not significantly affect practice adoption (data not shown). Based on the AN O VA model, comparison of adjusted means for net adoption indicated that each type of program differed significantly from other groups in the number of practices adopted (T able 2). M Gs adopted significantly more practices (6.9 practices) than those attending seminars ( 4.3 practices) and, in turn, persons attending seminars adopted more practices than participants who received publications only (2.6 practices).

On a practice-by-practice basis ( $T$ able 3 ), the number of $\mathrm{M}$ Gs using a practice significantly increased between the program's start and six months later for 28 of 39 practices studied. The number of seminar and publications-only participantsusing a practiceincreased for 31 and 6 practices, respectively. The nonparticipant group made a significant decrease in 8 of the practices, which suggests a tendency to overreport on the pretest by this group.

\section{Site analysis, planting, and landscape design}

M G and educational seminar participants made significant increases in the number who adopted recommended landscape design practices, while the nonparticipant group significantly decreased (Table 3). For M G and seminar participants, thenumber of thosegrouping plantsby water needsand maintenance needs, selecting plants adapted to site conditions, incorporating low-maintenance areas into their landscapes, and identifying sun and shade patterns increased 6 months after the programs. The publications-only group showed a significant increase for just one practice, planting in the proper sizehole, whilenonparticipants either decreased or showed no change in using recommended landscape design features and practices.

\section{Irrigation practices}

As with landscape design, M G trainees and seminar participants showed higher rates of adoption of irrigation practices. Each of these groups showed a significant increase for four of five practices. Preprogram surveysshowed that onethird or less of the participants watered their lawns when $30 \%$ to $40 \%$ of the grass blades fold (a sign of stress). Followup surveys showed that M Gs substantially increased (25\%) watering when the blades fold, followed by seminar (13\%) and comparison nonparticipants (8\%). All three types of program participants, M G, seminar and publications-only, increased the number who applied an appropriate amount of water per irrigation, ( $20 \%, 13 \%$, and $18 \%$ respectively). Thenonparticipant group decreased the number watering early in the morning or in theevening, a decrease that probably represents overreporting on the pretest survey.

\section{Fertilization}

Before the program delivery, participants reported varying rates of adoption for practices relating to recommended fertilizer practices. Preprogram surveys showed that less than two-thirds of respondents from each group were using slow release fertilizers, $<40 \%$ were fertilizing sparingly to reduce excessive growth, $<20 \%$ applied $1 \mathrm{lb}$ of nitrogen per $1000 \mathrm{ft}^{2}$ $\left(4.9 \mathrm{~kg} / 1000 \mathrm{~m}^{2}\right)$ of turf, and $<15 \%$ were using iron sulfate to green-up lawns. Followup surveys showed M G, seminar and publications-only participants made significant increases in the use of slow release fertilizers $(13 \%, 15 \%$ and $13 \%$ respectively), while nonparticipants made no change. Six months after the programs, the largest percent change in fertilizer practices exhibited by each group was in applying the appropriate amount of nitrogen; M Gs showed the largest increase (38\%) in adoption, followed by seminar participants (18\%). O ne practice that was not readily utilized before or after the

T able 2. Mean number of environmental landscape management practices adopted by type of program.

\begin{tabular}{lccc}
\hline $\begin{array}{l}\text { Program } \\
\text { type }\end{array}$ & $\begin{array}{c}\text { Practice used } \\
\text { before program } \\
\text { (mean no.) }\end{array}$ & $\begin{array}{c}\text { Practices } \\
\text { adopted }\end{array}$ \\
\hline M aster Gardener & 19.4 & 7.3 & (adj. net no. ${ }^{2}$ ) \\
Seminar & 17.9 & 4.5 & 6.9 \\
Publications only & 17.1 & 2.8 & 4.3 \\
N onparticipant group & 13.3 & 0.1 & 2.6 \\
\end{tabular}

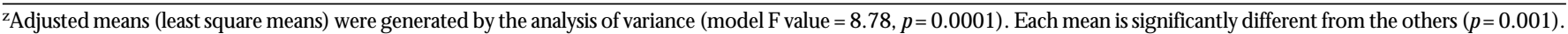




\begin{tabular}{|c|c|c|c|c|}
\hline \multirow[b]{2}{*}{ Practice } & \multicolumn{4}{|c|}{ Program type ${ }^{z}$} \\
\hline & $\begin{array}{c}\text { Master } \\
\text { G ardener }\end{array}$ & Seminar & $\begin{array}{c}\text { Publications } \\
\text { only }\end{array}$ & $\begin{array}{c}\text { Nonparticipant } \\
\text { group }\end{array}$ \\
\hline \multicolumn{5}{|l|}{ Site analysis, planting and landscape design } \\
\hline Group plants by water needs & 26.1 & 15.0 & --- & -7.0 \\
\hline Group plants by maintenance needs & 23.9 & 14.4 & --- & --- \\
\hline Select plants adapted to conditions & 16.4 & 9.4 & --- & -10.8 \\
\hline D esign low maintenance areas into landscape & 14.5 & 6.3 & --- & -8.6 \\
\hline I dentify sun and shade patterns & 12.7 & 10.3 & --- & --- \\
\hline Test the pH of the soil & 11.9 & --- & --- & --- \\
\hline Group plants into beds & 10.4 & --- & --- & -11.8 \\
\hline Select plants with moderate growth rates & -- & 19.1 & --- & -- \\
\hline Test soil for drainage & --- & 10.3 & --- & -5.9 \\
\hline Plant in holes twice as wide as the root ball & --- & --- & 15.3 & --- \\
\hline Plant root ball at proper depth & --- & --- & $\cdots$ & $\cdots$ \\
\hline Shade western $\&$ eastern walls of home & --- & --- & --- & -9.1 \\
\hline \multicolumn{5}{|l|}{ I rrigation } \\
\hline Water the lawn when the blades fold & 24.6 & 13.1 & --- & 8.0 \\
\hline Apply $1 / 2$ to $3 / 4$ inch $(1.3$ to $1.9 \mathrm{~cm}$ ) of water/ irrigation & 20.2 & 12.8 & 18.1 & --- \\
\hline Water plant bed separately from lawn & 19.4 & --- & --- & --- \\
\hline I rrigate according to season & 14.2 & 11.9 & --- & --- \\
\hline Water early in the morning or in the evening & --- & 9.1 & --- & -10.0 \\
\hline \multicolumn{5}{|l|}{ Fertilization } \\
\hline A pply $1 \mathrm{lb}$. of nitrogen/ $1000 \mathrm{ft}^{2}\left(4.9 \mathrm{~kg} / 1000 \mathrm{~m}^{2}\right)$ & 38.1 & 17.5 & --- & --- \\
\hline Fertilize sparingly to reduce the need to prune & 32.8 & 17.5 & --- & --. \\
\hline Fertilize with slow release components & 13.4 & 15.3 & 12.5 & --- \\
\hline U se iron sulfate to green up the lawn in summer & --- & 6.3 & --- & 7.0 \\
\hline \multicolumn{5}{|l|}{ Pest management } \\
\hline Routinely check landscape for pest problems & 29.9 & 12.5 & 15.3 & --- \\
\hline Choose pesticide least harmful to environment & 23.1 & 6.6 & --- & -9.7 \\
\hline Tolerate slight plant damage & 21.6 & 13.4 & $\cdots$ & --- \\
\hline Change cultural practices affecting the problem & 21.6 & 6.3 & --- & --- \\
\hline I dentify the problem before using chemicals & 20.9 & 11.3 & --- & --- \\
\hline Spot-treat only the infested area and buffer zone & 20.9 & --- & --- & --- \\
\hline Follow pesticide label instructions and warnings & 11.2 & 9.1 & --- & --- \\
\hline \multicolumn{5}{|l|}{ M owing and pruning } \\
\hline Prune branches in front of the branch collar & 31.3 & 10.9 & --- & --- \\
\hline M ow no more than $1 / 3$ of the grass blade & 17.0 & 6.3 & --- & --- \\
\hline Set mower blade at the appropriate height & 15.7 & 10.9 & --- & --- \\
\hline Sharpen mower blade when grass has ragged cut & --- & 13.1 & --- & --- \\
\hline \multicolumn{5}{|l|}{ Mulching } \\
\hline Pull much away from shrub stem and tree trunk & 32.1 & 10.6 & 16.7 & --- \\
\hline Increase the size of mulched areas around trees & 19.4 & 9.1 & --- & $--\cdot$ \\
\hline U se self-mulching areas under trees & 18.7 & 10.6 & --- & --- \\
\hline U se a compost pile & 12.7 & 5.9 & --- & $--\cdot$ \\
\hline L eave grass clippings to recycle nutrients & --- & 12.8 & --- & --- \\
\hline Add mulch to maintain 2 to 3 inch $(5.1$ to $7.6 \mathrm{~cm})$ depth & --- & 9.7 & 16.7 & --- \\
\hline A pply mulch in beds around trees and shrubs & --- & --- & --- & --- \\
\hline
\end{tabular}

${ }^{\mathrm{z}} \mathrm{N}$ onsignificant changes are denoted by a dashed line.

programs by any group wasuse of iron sulfatefor greening-up the lawn.

\section{Pest management}

Exception for spot-treating infested areas and changing cultural practices affecting a problem, a majority of participants were using recommended pest management practices before the program. Even so, a significant percentage of MG trainees adopted each of the recommended practices. Though the change was smaller than for $M \mathrm{Gs}$, a significant percentage of seminar participants also adopted six of seven pest management practices. In contrast, more publications-only participants routinely checked their landscape for pest problems after receiving educational materials but made no other significant changes. The nonparticipant group showed a decline in choosing the least harmful pesticide and no change on other pest management practices. 


\section{Mowing and pruning}

$M$ ore participants in educational seminars used each of the mowing and pruning practices at the time of the follow up than before the program. Similarly, a significant number of M G trainees adopted three of four practices. N either the publications-only participants nor nonparticipants adopted any practices at a significant level.

\section{Mulching}

For six of seven mulching practices, the percentage of participants in educational seminars using the practice increased at the time of the follow up survey. Similarly, a significant number of MG trainees adopted four of seven practices. Publications-only participants had significant increases for maintaining mulch depth and pulling mulch from stemsand trunks. Because $\approx 75 \%$ of participants used mulch in bedsaround trees and shrubs beforethe program, thispractice showed little change by any group. Again, the nonparticipant group showed no change for each mulching practice.

\section{Conclusions}

The evaluation demonstrated that each delivery method significantly increased use of recommended landscape maintenance practices by program participants in comparison to nonparticipants. M G trainees made the largest average increasein net adoption, probably reflecting theprogram'smore intensive educational experience. Similarly, participants who attended an educational seminar showed significant increases in use of many environmental landscaping practices. On the other hand, persons receiving publications only generally showed limited adoption of individual practices, though this was significant in the aggregate.

$O$ ne reason that the $M G$ training and educational seminars are more effective may be that an extension faculty member has the opportunity to lay the groundwork for printed information that participants receive, to explain the information in termsthat are moremeaningful to participants, and to motivate people to take action. A recent qualitative study found that peoplearemotivated to adopt environmental landscape practices when they are likely to reduce their workload, incur no extra cost, conform to neighborhood norms and prevent environmental damage (Salazar, 1997). When faculty members are present, as in M G training and educational seminars, they can address these customer concerns. In contrast, printed materials often focus on the techniques of environmental landscaping and omit discussion of how work is reduced, money saved and so on. For these reasons, program efforts should be redirected from the publications-only approach toward seminars that are complemented by publications. An alternativestrategy, whose impact would need to be evaluated, would beto revise E LM publicationsto explicitlyaddressissuesthatfacilitateorinhibithomeowners making changes in how they manage the landscape.

\section{Literature cited}

Beverly, R.B., W. Florkowshi, and J.M. Ruter. 1997. Fertilizer management by landscape maintenance and lawn care firms in Atlanta. H ortT echnology 7(4):442-445.

Campbell, D.T . and J.C. Stanley. 1963. Experimental and quasiexperimental designs for research. Rand M CN ally, C hicago.

Gilman, E.F. and S. Park Brown. 1991. Florida guide to environmental landscapes. U niv. Fla., G ainesville, Fla. Coop. Ext. Serv. SP114.

Karlik, J. 1992. A study in xeriscaping. Amer. Nurseryman. 179(2):72-77.

N elson, J.O . 1987. Water conserving landscapes show impressive savings. Amer. Water Works 79:35-36, 38-42.

Rossi, P.H . and H.E. Freeman. 1993. Evaluation: A systematic approach. 5th ed. Sage, N ewberry Park, Calif.

Salazar, B. 1997. Social marketing study of individuals' environmental landscape practices. Chastain Skillman Inc., Tampa, Fla., CSI File N 0. 6209.01.

Sokal, R.A. and F.J. Rohlf. 1995. Biometry: The principles and practice of statistics in biological research. Freeman, N ew York. 